\title{
Perspektywa wykorzystania badań nad systemem-światem w analizie stosunków międzynarodowych w XXI wieku
}

\author{
Perspectives of Application the World-Systems Analysis Approach \\ in the Study on International Relations in $21^{\text {st }}$ Century
}

\section{- Abstrakt •}

Artykuł przedstawia zarys badań nad szkołą World-Systems Analysis (WSA), związaną z pracami Immanuela Wallersteina i czasopismami Review. A Journal of the Fernand Braudel Center oraz Journal of World-Systems Research. Środowisko to tworzy wpływowy nurt $\mathrm{w}$ historii gospodarczej i socjologii rozwoju. Jego dorobek jest też niekiedy wykorzystywany przez badaczy stosunków międzynarodowych. Tekst przedstawia główne założenia teoretyczne i problemy badawcze podejmowane w ramach WSA, diagnozuje kondycję i zarysowuje perspektywy rozwoju tej orientacji we współczesnych naukach społecznych.

Słowa kluczowe: gospodarka światowa, system-świat, historia gospodarcza, Immanuel Wallerstein

\section{- Abstract •}

This article outlines the research programme on World-Systems Analysis school, which is connected with works of Immanuel Wallerstein and periodicals Review. A Journal of the Fernand Braudel Center and Journal of World-Systems Research. This scientific community has set up influential theories and research position in economic history and sociology of development. My text examines the crucial research problems and theoretical assumptions of WSA approach. Besides this, condition and perspectives of WSA within contemporary social sciences is analysed.

Keywords: global economy, world-system, economic history, Immanuel Wallerstein

\section{Wprowadzenie}

Celem artykułu jest wstępna analiza dorobku szkoły systemów-światów (World-Systems Analysis, WSA) i ocena perspektyw jej stosowania w badaniach nad stosunkami międzynarodowymi. Układ treści jest następujący - w części pierwszej przeglądowo zrekonstruowane zostanie podłoże teoretyczne WSA. W części drugiej omówione zostaną podstawowe kategorie. W części kolejnej przedstawię prze- 
gląd dorobku naukowego i zarysuję program dalszych prac. Projekt jest elementem szerszych studiów, których zadaniem będzie wykorzystanie narzędzi WSA w analizie pozycji Polski i Europy Środkowej w polityce i gospodarce światowej.

Dorobek WSA wiąże zagadnienia badawcze historii gospodarczej, socjologii historycznej oraz socjologii rozwoju i globalizacji. Jest to interdyscyplinarne podejście do nauk społecznych. Badania nad tym podejściem są ważne, ponieważ stosuje się w nim kategorie dotyczące węzłowych problemów współczesnego świata. Mowa tu o takich tematach, jak: stratyfikacja w systemie międzynarodowym, centra i peryferie rozwoju, trendy zmian w polityce i gospodarce światowej, metodologia historii i nauk społecznych, teorie globalnych zmian społecznych, zagadnienie kapitalizmu, znaczenie państw w zapewnianiu rozwoju i bezpieczeństwa, naukowo-technologiczne i ekonomiczne aspekty zmian w stosunkach międzynarodowych i inne. W badaniu tych kwestii konieczne jest sięganie do różnych dziedzin wiedzy. Mnie osobiście interesuje systemowa perspektywa nauki o stosunkach międzynarodowych (NSM), którą wykorzystałem w swoich wcześniejszych pracach (Pawłuszko, 2014a, 2014b). Systemowa tradycja naukowa będzie mi najbliższa w procesie interpretacji omawianego zjawiska. W pracy wykorzystałem metodykę krytycznej analizy treści, podejście porównawcze, oparte na badaniu argumentacji i pojęć, stosowanych w różnych szkołach badawczych.

\section{Zainteresowanie szkołą WSA}

Zainteresowanie pracami Immanuela Wallersteina i jego uczniów wśród badaczy stosunków międzynarodowych w Polsce było dotąd relatywnie niewielkie. Sam Wallerstein uważa się za pioniera koncepcji „historycznych nauk społecznych”, a zasadniczo za socjologa. Niemniej, jego dorobek rozpatrywany jest też w ramach międzynarodowej ekonomii politycznej, która jest subdyscypliną nauki o stosunkach międzynarodowych. W Polsce ukazało się kilka monografii podejmujących problematykę WSA. Należą do nich prace J. Swianiewicza (2014), J. Ilkowskiego (2015), T. Klementewicza (2013; 2015), A. Gałganka (1992; 2013), a także T. Zaryckiego (2009; 2016). Zwracają naszą uwagę również publikowane w czasopismach artykuły J. Hryniewicza (2010; 2013), A. Aleksy (2005), G. Ziewiec (2009) bądź M. Rewizorskiego (2009). Podejście WSA uwzględnia w swoim podręczniku z 2006 roku J. Czaputowicz (2006), aczkolwiek po opublikowaniu wyników szerokich badań ilościowych w 2015 roku wskazuje, że oddźwięk tego podejścia jest w Polsce znikomy (Czaputowicz, Ławniczak, Wojciuk, 2015). Jednakowoż, niedawna popularyzacja międzynarodowej ekonomii politycznej (interna- 
tional political economy, IPE) w dyskursie poświęconym teorii stosunków międzynarodowych może zwrócić uwagę badaczy na to podejście. W tym wątku można zwrócić uwagę na przekład zbiorowej pracy pod red. Johna Ravenhilla (Ravenhill, 2012) oraz książkę Geoekonomia, popularyzowaną po 2012 roku przez E.M. Haliżaka i środowisko Zakładu Ekonomii Politycznej Stosunków Międzynarodowych UW (Haliżak, 2012). Pewną popularność zdobywa w Polsce podejście postkolonialne, które również odwołuje się w swoich ustaleniach do szkoły WSA (Gawrycki, Szeptycki, 2011; Polus, 2014).

Dostępne są w języku polskim nieliczne prace I. Wallersteina takie, jak: Koniec świata, jaki znamy (2004), Analiza systemów-światów: wprowadzenie (2007), Europejski uniwersalizm: retoryka władzy (2013) oraz redagowane przez niego prace zbiorowe Utopistyka: alternatywy dla XXI wieku (2008) i Czy kapitalizm ma przyszłość? (2015). Dominują prace eseistyczne. Programowe teksty tego autora nie są przetłumaczone i rzadko znajdziemy ich argumentację w polskiej debacie naukowej. Pojawiają się w dyskusjach publicystycznych na łamach czasopism związanych ze środowiskami lewicowymi. Prace innych autorów, wiązanych na świecie z WSA, takich jak: Giovanni Arrighi (Arrighi, 1994), Andre Gunder Frank (Frank, 1990), Christopher Chase-Dunn (Chase-Dunn, 1998) czy Samir Amin (Amin, 1994), znane są tylko wąskim grupom badaczy.

Polski dorobek korespondujący tematycznie związany z pracami szkoły WSA znajdziemy częściej w klasycznych pracach tzw. polskiej szkoły historii gospodarczej W. Kuli (Kula, 1983), J. Topolskiego (Topolski, 1977), M. Małowista (Małowist, 1973) czy J. Kochanowicza (Kochanowicz, 1990; Kochanowicz, 2006), którzy zajmowali się genezą kapitalizmu i historycznym rozwojem gospodarki światowej. Spór polskich historyków w tym temacie w wyczerpującym studium omówiła A. Sosnowska. Sam Immanuel Wallerstein w swoich pracach odwoływał się często do publikacji M. Małowista (Małowist, 1966). Polscy historycy mieli długie i głębokie związki ze słynną francuską szkołą Annales, kierowaną przez Marca Blocha (Bloch, 1960), a następnie Fernanda Braudela (Braudel, 1971). Pod dużym wrażeniem tego ostatniego był również przebywający na stypendium w Paryżu I. Wallerstein. Szkoła ta promowała holistyczne i społeczno-gospodarcze podejście do historii świata. Zalecała też badanie zjawisk historycznych w długiej perspektywie.

Pod wrażeniem metod historiografii promowanej przez Annales po powrocie do USA I. Wallerstein opublikowat w 1974 roku pierwszy tom The Modern World-System (1974b). Następnie w 1976 roku założył w strukturze State University of New York in Binghamton własny instytut, nazwany Fernand Braudel Center for the Study of Economies, Historical Systems and Civilizations (w skrócie Fernand Braudel Center). Historia projektów badawczych zorganizowanych w tym 
instytucie opisana jest szczegółowo na jego stronie internetowej ${ }^{1}$. Jednym z nich jest do dziś czasopismo Review. A Journal of the Fernand Braudel Center. W okresie 1994-1998 Wallerstein był przewodniczącym prestiżowego International Sociological Association. W tym czasie (1994) powstał również periodyk pod redakcją Ch. Chase-Dunna Journal of World-Systems Research, który przyciąga autorów z całego świata. Od 2008 roku czasopismo jest afiliowane przy American Sociological Association (sekcja Political Economy of the World System)². Jednocześnie należy zauważyć, że w innych towarzystwach naukowych (International Studies Association, International Political Science Association) WSA nie doczekała się odrębnej sekcji badawczej. Również istniejące w naszym kraju Polskie Towarzystwo Studiów Międzynarodowych nie posiada oddzielnej sekcji. Prace mogą pojawiać się w wątku wspomnianej międzynarodowej ekonomii politycznej3.

W trzydziestolecie i czterdziestolecie publikacji pierwszego tomu The Modern World-System odbyły się w czasopismach socjologicznych dyskusje o kryzysie teorii WSA, ale krąg badaczy zajmujących się tematem wcale nie zmalał (Sanderson, 2005; El-Ojeili, 2014). W roku 2012 globalne wydawnictwo Routledge opublikowało pod redakcją wspomnianych S. Babonesa i Ch. Chase-Dunna przekrojowy Routledge Handbook of World-Systems Analysis, który zebrał blisko 70 tekstów, tworzących panoramę wielu aspektów analizy WSA (Babones, Chase-Dunn, 2012). Co ciekawe, sam I. Wallerstein nie określił WSA mianem teorii czy paradygmatu. W posłowiu do tej publikacji nazwał istniejące środowisko raczej „ruchem wiedzy", tudzież ruchem naukowym (knowledge movement). Stwierdzenie to koresponduje z wcześniejszymi wypowiedziami tego autora, iż jego celem jest budowa unidyscyplinarnych nauk humanistycznych poprzez łączenie wiedzy nauk historycznych, ekonomicznych i społecznych. Współczesny kryzys humanistyki i nauk społecznych wynika bowiem, zdaniem tego autora, z podziału i specjalizacji nauk, dokonanej w XIX wieku w epoce dominacji liberalnego myślenia o świecie (Wallerstein, 2013). To z myślenia liberalnego wynika podział na oddzielne sfery życia badane przez różne nauki: socjologię (przedmiot badań: społeczeństwo obywatelskie), politologię (przedmiot badań: polityka) i ekonomię (przedmiot ba-

\footnotetext{
${ }^{1}$ Report on an Intellectual Project: The Fernand Braudel Center, 1976-1991 http://binghamton. edu/fbc/about-fbc/intellectual-report.html (dostęp: 19.12.2016).

2 Strona internetowa tej sekcji jest powszechnie dostępna http://asapews.org/.

${ }^{3}$ American Sociological Association posiada sekcję Political Economy of the World System; International Studies Association posiada sekcje: global development studies oraz international political economy, a International Political Science Association: również International Political Economy oraz Rethinking Political Development; w ramach PTSM istnieje Sekcja Międzynarodowej Ekonomii Politycznej.
} 
dań rynek). Celem szkoły WSA jako ruchu naukowego byłoby zatem łączenie podejść tych nauk w jedną całość.

\section{Główne założenia badań}

Szkoła WSA pojawiła się na pewnym etapie sporu teorii modernizacji i teorii zależności, stając po stronie tej drugiej. Zdaniem teorii modernizacji, propagowanej w okresie powojennym przez liberałów, wszystkie państwa rozwijające się powinny naśladować drogę państw rozwiniętych (por. Jasiecki, 2009). Krytycy tego podejścia argumentowali, że każdy kraj ma swoją historię i drogę rozwoju, a naśladownictwo krajów bogatych doprowadzi jedynie do zależności. Raul Prebisch dla opisu tego procesu zaproponował w 1959 roku schemat centrum-peryferie (Prebisch, 1959). Zgodnie z tą teorią niedorozwój wielu państw ma charakter strukturalny. Kraje biedniejsze (peryferie) są wykorzystywane przez kraje bogatsze (centrum). Tezy tego podejścia celnie streścił J. Hryniewicz (Hryniewicz, 2013, 296-297):

1. Z czasem zyskowność produktów spada i ich produkcja przenoszona jest do peryferii.

2. Powyższy mechanizm sprzyja stabilności społecznej w państwach centrum.

3. Kapitalizm finansowy niekonieczne musi zasilać gospodarkę realną.

4. Spekulacje finansowe w centrum mogą zdestabilizować peryferie.

5. Im wyższy poziom uczestnictwa państwa peryferii w gospodarce, tym większe jego relatywne straty i wyższe zyski państw centrum.

Po piętnastu latach od ogłoszenia tej teorii Immanuel Wallerstein przeniósł mechanizm centrum-peryferie na stosunki międzynarodowe $\mathrm{w}$ skali globalnej i wprowadził pojęcie systemu-świata, zwanego też niekiedy systemem światowym. Zjawisko to można zdefiniować jako uniwersalny, międzykulturowy i międzynarodowy podział pracy związany z rozwojem zasad kapitalizmu (Babones, 2014). Pierwszy prawdziwie globalny system społeczny nie został wytworzony przez jednolitą kulturę ani jednostkę polityczną, stał się nim dopiero rynek. Zdaniem Wallersteina system ten rozprzestrzenił się na cały świat na początku XVI wieku wraz z ekspansją zamorską państw europejskich. W tej konstrukcji teoretycznej amerykański socjolog wykorzystał kilka wątków: historyzm grupy Annales, marksistowskie przekonanie o międzynarodowym konflikcie klasowym, południowoamerykańską teorię zależności, a także prace ekonomistów: Karla Polanyiego (podział zasad społecznych na rynkowe, redystrybucyjne i tradycyjno-wymienne) i Josepha Schumpetera (teoria cykli koniunkturalnych, teoria innowacji), którzy krytykowali liberalne podejście do rynku (Polanyi, 2010; Schumpeter, 1960). 
Dokonując syntezy powyższych składników, wskazał Wallerstein na mechanizm podobny do centrum-peryferie. Jego zdaniem technologia produkcji pozycjonuje region w gospodarce światowej, co tworzy strukturę tej gospodarki: centra, półperyferie i peryferie. Status państw i regionów w takim systemie jest reprodukowany, opiera się bowiem na nierównej wymianie. Centrum dąży do takiej struktury gospodarki, która faworyzuje państwa rozwinięte i produkujące towary wysoko przetworzone. W krajach rozwiniętych sektor eksportowy jest motorem wzrostu, korzystają na tym też pracobiorcy, przez co spada niezadowolenie społeczne. Peryferia opierają się na produkcji i eksporcie dóbr niższej technologii, przejmując je z państw bogatszych. W ten sposób finansują bezpieczeństwo socjalne w państwach centrum. Nierówna wymiana, opierająca się na wartości dodanej z wytwarzanych dóbr, prowadzi do akumulacji zasobów w krajach centralnych. Państwa próbują wykorzystać swoją przewagę tworząc mechanizm powstawania hegemonii - a więc dominacji symbolicznej centrum nad peryferiami i półperyferiami. Salvatore Babones uważa, że celem tego typu analizy jest poznanie globalnych wzorców władzy i dominacji, a także wykazanie, że relacje siły i zależności mają tak naprawdę charakter transnarodowy (Babones, 2015).

Pod koniec epoki przemysłowej likwidowano na Zachodzie opłacalne i dobrze płatne stanowiska pracy w przemyśle, nowa praca czekała w usługach i była relatywnie gorzej płatna. Płace realne spadły u $80 \%$ pracowników. Tym samym wzrosła rozpiętość dochodów. Niemniej jednak, niepokojów społecznych w państwach centrum nie było, gdyż w tym czasie zapewniono lepszą opiekę społeczną, a ceny towarów przeniesionych do tanio produkujących peryferii spadły. Podstawowe dobra staniały i obywatele państw zamożnych nie odczuli pogorszenia standardu życia. Jak pisze J. Hryniewicz: urządzenia, odzież, wychowanie, rozrywki, meble - relatywnie staniały (dane za Consumer Price Index). Przemysł stał się atrybutem państw peryferyjnych, centrum zaś tworzy produkty wiedzochłonne (Hryniewicz, 2013). Peryferie zaś dzielą się na surowcowe i przemysłowe. Państwa surowcowe mają najgorsze terms of trade. Natomiast państwa półperyferyjne pośredniczą między centrami a peryferiami, posiadając zasadniczo efektywne struktury państwowe, lecz zbyt słaby potencjał (głównie instytucjonalny!), aby dołączyć do centrum. Sytuacja ta przez dekady dotyczyła m.in. Indii, Rosji i Turcji, które dołączyły do masowego obrotu handlowego w XVII wieku, ale posiadały niewielką konkurencyjność i na dłuższą metę nie wytrzymały rywalizacji z uprzemysłowionymi krajami Zachodu. Rosji nie udało się przełamać gospodarczego monopolu Zachodu nawet w czasie trwania ZSRR.

Według klasycznych prac I. Wallersteina w historii możliwe są trzy sposoby na dołączenie państwa do klubu najbogatszych państw świata: wykorzystanie okazji, 
zaproszenie oraz protekcjonizm (por. Aleksy, 2005). Zdaniem S. Babonesa współcześnie możliwość dołączania do centrum jest bardzo utrudniona. Według niego struktura bogactwa na świecie obecnie nie różni się zasadniczo od tej sprzed stu lat (np. terytorium Polski jest obecnie na takim poziomie rozwoju w relacji do państw Zachodu jak było przed I wojną światową). Możliwy jest zwykle awans z peryferii do półperyferii, ale już nie do centrum (Babones, 2016). Drobne wyjątki dotyczą niedużych miast-państw, specjalizujących się w usługach i przemyśle wysokich technologii, takich jak: Hongkong, Singapur, Korea Południowa (42\% jej terytorium to metropolia Seulu). Autor ten nie wierzy w długotrwały awans gospodarek surowcowych, takich jak Arabia Saudyjska, wnioskując na podstawie zatrzymania, bazującego na surowcach, rozwoju państw latynoamerykańskich w połowie $\mathrm{XX}$ wieku. Inne znane przypadki, takie jak Japonia i kraje skandynawskie, również były sto lat temu na stosunkowo wysokim poziomie gospodarczym (Pawłuszko, 2015). Ci, którzy byli bogaci sto lat temu, są bogaci i dzisiaj. Jak pokazał A. Leszczyński, większość strategii polityki rozwoju po II wojnie światowej w Azji, Afryce i na terenie ZSRR - poniosła porażkę (Leszczyński, 2013).

Współcześnie teoria ta napotyka na poważne wyzwania, ponieważ musi uwzględniać nowy podział pracy, oparty na wiedzy i kapitale wirtualnym, który zastąpił akumulację wynikającą z handlu w gospodarce realnej (Hryniewicz, 2013). W świecie obecnym doszło do kompresji czasu i zwiększenia zmienności i nieprzewidywalności stosunków społecznych. Przepływy inwestycji, wartość dodana i łańcuchy wartości w gospodarce wirtualnej stały się bardzo zmienne. $\mathrm{Na}$ znaczenie wiedzy i innowacji w rozwoju państw w systemie międzynarodowym zwracał uwagę harwardzki historyk David Landes (Landes, 2007), a za nim, m.in. w Polsce, Anna Wojciuk (Wojciuk, 2016). Wiedza nie jest klasycznym zasobem ekonomicznym, który można łatwo spieniężyć i wycenić. Według A. Koźmińskiego i D. Jemielniaka wiedza jest zasobem niewyczerpalnym, nie ma granic zasięgu intensywności i zastosowania, oraz doskonale odnawialnym - wykorzystywana, rozwija się - nie podlega prawu malejących przychodów. Nie ma obiektywnych granic nakładów na wiedzę, wycena ex ante jest niemożliwa, a ex post bywa niebotycznie wysoka (Koźmiński, Jemielniak, 2008, 9-10). Jest to również jeden z tematów, które należy podjąć w przyszłości.

Zdaniem Immanuela Wallersteina hegemonia w systemie światowym nie jest uzależniona od posiadania jakiegoś zestawu „czynników potęgi”. W ciągu kilkuset lat różne państwa dominowały korzystając z rozmaitych innowacji społecznych i instytucjonalnych. Naturalnie, niemal zawsze występowała korelacja pomiędzy dominacją $\mathrm{w}$ systemie, a wysokim poziomem gospodarczym, posiadaniem kluczowych gałęzi produkcji czy potencjałem militarnym, ale żadne z nich nie jest 
trwałym wskaźnikiem w dłuższej perspektywie. Wszystkie przewagi mają charakter okresowy. Do podobnych wniosków doszedł, amerykański badacz polskiego pochodzenia, George Modelski.

Zdaniem G. Modelskiego państwa próbują zarządzać systemem (Modelski, 1974, Modelski 1978). Niektóre państwa dominowały w historii, a ich dominacja wynikała z dwóch warunków: konieczności zapewnienia porządku globalnego oraz specjalnych cech systemu, które premiują zmienne rozwiązania. Dlatego brak stałych wzorców charakteryzujących systemy i ich zmiany. Według Wallersteina system ma jednak podłoże ekonomiczne, ponieważ globalne stosunki społeczno-polityczne są funkcją alokacji dóbr na światowym rynku. Poziom relacji państw jest dla niego mniej istotny i wtórny względem relacji centrów, peryferii i półperyferii.

Wallerstein w swoich pracach propagował również koncepcję cykli rozwoju (kontrowersyjne cykle Kondratiewa), ale nie uważał jej za obowiązkowy składnik podejścia WSA (por. Wallerstein, 2004, 15-30). Skłaniał się z czasem ku badaniu znaczenia wybranych wydarzeń i faktów w kontekście centro-peryferyjnym. Zyskują one znaczenie w epoce współczesnej, która charakteryzuje się powrotem Azji do kluczowej roli w globalnym systemie ekonomicznym. Państwa Zachodu nadal są krajami centralnymi, dominującymi technologicznie, symbolicznie, ekonomicznie, politycznie i militarne, ale wszystkie wymiary tej przewagi ewoluują. Będzie to jedno z najbardziej frapujących zagadnień stosunków międzynarodowych XXI wieku.

Tabela 1. Zarządzanie systemem międzynarodowym - długie cykle George’a Modelskiego

\begin{tabular}{|l|l|l|l|l|}
\hline $\begin{array}{l}\text { Potęga } \\
\text { światowa }\end{array}$ & $\begin{array}{l}\text { Konflikt } \\
\text { inicjujący }\end{array}$ & Legitymizacja & $\begin{array}{l}\text { Innowacje } \\
\text { instytucjonalne }\end{array}$ & Upadek \\
\hline Portugalia & $\begin{array}{l}\text { Wojny włoskie } \\
(1494-1517)\end{array}$ & $\begin{array}{l}\text { Traktat } \\
\text { w Tordesillas }\end{array}$ & $\begin{array}{l}\text { Organizacja wypraw } \\
\text { dalekomorskich, } \\
\text { sieć baz } \\
\text { zaopatrzeniowych }\end{array}$ & $\begin{array}{l}\text { Dominacja } \\
\text { Hiszpanii, } \\
\text { konflikty religijne }\end{array}$ \\
\hline Niderlandy & $\begin{array}{l}\text { Wojny } \\
\text { hiszpańskie } \\
(1579-1609)\end{array}$ & $\begin{array}{l}\text { Zakończenie } \\
\text { wojny } \\
\text { o niezależne } \\
\text { Niderlandy }\end{array}$ & $\begin{array}{l}\text { Zasada wolności } \\
\text { mórz, bank } \\
\text { amsterdamski, } \\
\text { Kompania } \\
\text { Wschodnio- } \\
\text {-Indyjska }\end{array}$ & $\begin{array}{l}\text { Wojna z Anglią } \\
\text { i Francją, } \\
\text { rewolucja angielska }\end{array}$ \\
\hline
\end{tabular}


Tab. $1-\mathrm{cd}$.

\begin{tabular}{|c|c|c|c|c|}
\hline $\begin{array}{l}\text { Potęga } \\
\text { światowa }\end{array}$ & $\begin{array}{l}\text { Konflikt } \\
\text { inicjujący }\end{array}$ & Legitymizacja & $\begin{array}{l}\text { Innowacje } \\
\text { instytucjonalne }\end{array}$ & Upadek \\
\hline $\begin{array}{l}\text { Wielka } \\
\text { Brytania } \\
\text { (pierwszy cykl) }\end{array}$ & $\begin{array}{l}\text { Wojna z Francją } \\
(1688-1713)\end{array}$ & $\begin{array}{l}\text { Traktat } \\
\text { w Utrechcie }\end{array}$ & $\begin{array}{l}\text { Organizacja } \\
\text { floty, europejska } \\
\text { równowaga sił, } \\
\text { kontrola nad } \\
\text { handlem morskim, } \\
\text { dług publiczny, } \\
\text { Bank Anglii }\end{array}$ & $\begin{array}{l}\text { Niezależność } \\
\text { USA, rozbiory } \\
\text { Polski, rewolucja } \\
\text { francuska }\end{array}$ \\
\hline $\begin{array}{l}\text { Wielka } \\
\text { Brytania } \\
\text { (drugi cykl) }\end{array}$ & $\begin{array}{l}\text { Wojny } \\
\text { napoleońskie } \\
(1792-1815)\end{array}$ & $\begin{array}{l}\text { Kongres } \\
\text { wiedeński }\end{array}$ & $\begin{array}{l}\text { Rozwój floty, } \\
\text { rewolucja } \\
\text { przemysłowa, } \\
\text { niezależność } \\
\text { Ameryki Łacińskiej, } \\
\text { otwarcie Chin } \\
\text { i Japonii }\end{array}$ & $\begin{array}{l}\text { Wyścig zbrojeń } \\
\text { morskich } \\
\text { z Niemcami, } \\
\text { Imperializm, } \\
\text { rewolucja w Rosji, } \\
\text { Wielki Kryzys }\end{array}$ \\
\hline $\begin{array}{l}\text { Stany } \\
\text { Zjednoczone }\end{array}$ & $\begin{array}{l}\text { Wojny światowe } \\
\text { z Niemcami } \\
\text { (1914-1918, } \\
\text { 1939-1945) }\end{array}$ & $\begin{array}{l}\text { Traktat } \\
\text { wersalski } \\
\text { i umowa } \\
\text { jałtańska }\end{array}$ & $\begin{array}{l}\text { ONZ, odstraszanie } \\
\text { nuklearne, } \\
\text { korporacje } \\
\text { wielonarodowe, } \\
\text { podbój kosmosu, } \\
\text { dekolonizacja }\end{array}$ & $\cdots$ \\
\hline
\end{tabular}

Źródło: G. Modelski, The Long Cycle of Global Politics and the Nation State, "Comparative Studies in Society and History", t. 20, nr. 2 (1978), s. 225.

\section{Krytyka podejścia WSA}

Krytyka teorii związanych z WSA pojawiła się już na końcu lat 70. XX wieku, m.in. w pracach Thedy Skocpol (Skocpol, 1977) i Petera Worsleya (Worsley, 1980). Niemniej jednak podejście to zyskało szeroką popularność w latach 80 ., gdy na gruncie NSM nurt ten był określany mianem globalizmu i zdobył pozycję jednego z trzech głównych nurtów teorii stosunków międzynarodowych. Załamanie się ładu dwubiegunowego spowodowało kryzys w NSM, ale koncepcje propagowane w ramach WSA miały się bardzo dobrze. Łączenie wątków ekonomicznych i socjologicznych pozwoliło badaczom z tej szkoły zająć się procesami globalizacji, który to temat okazał się kluczowy dla nauk społecznych lat 90 . W tym samym czasie badacze stosunków międzynarodowych rezygnują z badań systemowych na rzecz węższych ujęć politologicznych. WSA stało się zagadnieniem wią- 
zanym ponownie z socjologią globalizacji i historią gospodarczą oraz zagadnieniami takimi, jak: nierówność, handel, zwycięzcy i przegrani globalizacji czy badanie perspektyw na XXI wiek. W drugiej dekadzie XXI wieku, po kryzysie finansowym z 2008-2009 roku, obserwujemy ponowne zainteresowanie historią gospodarczą. Wiele środowisk intelektualnych zastanawia się, czy uda się podtrzymać zachodni styl życia w XXI wieku w sytuacji kryzysu demograficznego i wzrostu znaczenia Azji w polityce i gospodarce światowej.

Rozwój badań WSA, który obserwujemy na łamach czasopism Review oraz Journal of World-Systems Research (jedno z pierwszych na świecie czasopism naukowych online), wskazuje na główne tematy współcześnie podejmowane w tej szkole. Są nimi z pewnością metodologia badań systemowych i porównawczych (Babones, 2009; Moran, 2009; Gellert, 2009; Korotayev, 2005), zmiany w naukach społecznych (Rojas, 2000), globalizacja i jej problemy (Chase-Dunn, 2013; Markoff, 1999; Sklair; 1999) finansjeryzacja (Brewer, 2011; Chase-Dunn, 2013), międzynarodowy podział pracy (Goldfrank, 1995; Mahutga, 2014), rozwój miast (Wilkinson, 2002; Thomas, 2012), demografię (Danna, 2014), kwestie czasu i przestrzeni (Friedmann, 2000; Therborn, 2000; Agnew, 2001) rozwój państw centrum (Bagchi, 2000; Terlouw, 2011), status krajów peryferyjnych i pół-peryferyjnych (Boatca, 2006; Schwartzman, 2006). Podejmowana jest też oczywiście problematyka historii systemu-świata (Modelski, 2005; Turchin, 2006) i rozwoju samej szkoły (Frank, 2000; Lloyd, Mahutga and De Leeuw, 2009; Williams and Wallerstein, 2013).

Badaczom systemu-świata nie umyka krytyka i zmiany w ich podejściu do obserwowanych problemów. Zdaniem Ch. El-Ojeili problemem WSA jest swego rodzaju redukcjonizm, determinizm (zob. Ojeili, 2014), teleologizm (spór Franka i Wallersteina na początku lat 90. XX wieku o długość trwania systemu międzynarodowego, por. Frank, 2000), reifikacja kategorii systemu, sztywność ról przydawanych państwom i regionom, niedostrzeganie znaczenia inwestycji zagranicznych oraz kwestii egzogenicznych i endogenicznych (Sanderson, 2005) czy też poglądy socjalistyczne liderów ruchu. Zdaniem krytyków WSA powinna być koncepcją bardziej elastyczną.

Kluczowe kategorie WSA to centra i peryferie, dominacja ekonomii nad kulturą i polityką, hegemonia, cykliczność etapów rozwoju i historyzm. Stephen Sanderson, próbując ująć tezy WSA w jednym miejscu, wskazuje na kilkanaście zagadnień: (1) w świecie istniało wiele systemów; (2) system-świat jest podstawową jednostką analizy; (3) dwa podstawowe typy systemów to gospodarki-światy (całości obiegu gospodarczego) i imperia-światy (całości zjednoczone politycznie lub militarnie); (4) w XVI wieku powstała globalna gospodarka-świat; (5) oznacza 
to kluczową zmianę w historii; (6) struktura gospodarki-świata jest trzyczęściowa - centrum/rdzeń, półperyferie i peryferii; (7) rdzenie eksploatują pół-peryferia, a te z kolei eksploatują peryferii; (8) rywalizacja w centrum toczy się o nadwyżki zysku; (9) zmiany pozycji w systemie są rzadkością; (10) gospodarka-świat poszerza się i/lub pogłębia; (11) cztery podstawowe trendy to mechanizacja, komodyfikacja, proletaryzacja i polaryzacja społeczna; (12) w gospodarce-świecie istnieją również trendy cykliczne i cykle hegemonii; (13) do tej pory hegemonii w gospodarce-świecie były cztery; (14) współczesny system-świat (modern world-system) składa się z gospodarki-świata i systemu międzypaństwowego, powiązanych kwestią akumulacji kapitału i tworzenia się hierarchii regionów w wyniku międzynarodowego podziału pracy; (15) system ten jest w kryzysie i prawdopodobnie upadnie w XXI wieku; (16) kapitalistyczny w swych zasadach system-świat zostanie w przyszłości zastąpiony bardziej racjonalnym i „ludzkim” systemem społecznym (por. Sanderson, 2005, 180-185).

Zdaniem Sandersona obecnie tezy nr 1, 3, 4, 5, 8, 10, 11, 13, 14, 15 mogą być nadal akceptowane na podstawie aktualnych wyników badań. Wątpliwości dotyczą tez 2, 6, 7, 12, 16, które wymagają przeformułowania lub odrzucenia w części (temat ten będzie dalszą częścią moich badań). Autor ten uważa, że należy w całości odrzucić tezę numer 9. Jego zdaniem dochodzi do częstych zmian w pozycjonowaniu się państw na świecie. Niektóre państwa awansują z peryferii do statusu półperyferii, inne nawet do statusu krajów centrum/rdzenia. $Z$ autorem tym nie zgadza się $S$. Babones, powołujący się na dane statystyczne w długiej perspektywie czasowej, potwierdzając, że struktura podziału dochodu na świecie jest względnie stała i na ponad sto badanych państw jedynie kilka zanotowało trwały wzrost pozycji w systemie (2016, 13-20). Awans do centrum gospodarki-świata udał się zasadniczo tylko kilku małym krajom, opierającym się na usługach. Na tej podstawie uważa, że nie ma potrzeby rezygnowania zarówno z tezy nr 9, jak i powiązanych z nią zagadnień stratyfikacji i ról w systemie-świecie.

Jak widzimy, podejście WSA tworzy liczne powiązania pomiędzy gospodarką a społeczeństwami i polityką. Skomplikowanie współczesnych badań powoli powoduje jednak rezygnacje z funkcji prognostycznych nauki. Badacze związani z podejściem WSA mniej chętnie używają teorii cykli, ponieważ zmienność społeczna epoki mediów masowych jest nieporównywalna w stosunku do trendów obserwowalnych jeszcze pół wieku temu. W związku z tym traktuje się cykle raczej jako perspektywę, aniżeli rygorystyczną teorię prognostyczną, wyprowadzaną z postulatu determinizmu. Przykłady niespójnych lub niecelnych prognoz związanych z teorią cykli zebrał w swojej pracy na początku lat 90. Andrzej Gałganek (1992). W myśl idei Thomasa Kuhna i Imre Lakatosa zużyte i niefunkcjonalne 
teorie i programy badawcze są zastępowane innymi, które lepiej tłumaczą rzeczywistość społeczną. W XXI wieku obserwujemy ponowny wzrost zainteresowania badaniami jakościowymi i teoriami średniego zasięgu.

\section{Podsumowanie}

Perspektywy badań szkoły WSA w ramach teorii stosunków międzynarodowych pozostają szerokie. Minęło ćwierćwiecze od momentu opublikowania pracy A. Gałganka poświęconej globalistycznym teoriom stosunków międzynarodowych. Tematy centrów i peryferii, relacji zależności i współzależności nabrały tymczasem na znaczeniu po akcesji Polski do NATO i UE. Słabość polskiej gospodarki, instytucji, infrastruktury czy armii rozpatrywana jest w relacji do krajów „UE-15”. Porównania nie wypadają korzystnie. Polska szuka dobrej teorii rozwoju, pozwalającej zmniejszyć dystans do zamożnych krajów Zachodu. W ramach tych poszukiwań ogłaszane są kolejne strategie rozwoju państwa i jego regionów. Kryzys finansowy 2008 roku i późniejsze kryzysy w UE prowadzą do dyskusji o modelu rozwoju krajów Zachodu. Jak zwróciliśmy uwagę wcześniej, znaczenia nabiera ponownie dyskusja o modelu kapitalizmu i jego odmianach w historii gospodarczej. W tym obszarze teorie WSA mają bogaty dorobek. Na tle polskich badań teoria ta niesie szerszy i bardziej interdyscyplinarny potencjał wyjaśniania niż teorie realizmu politycznego czy liberalizmu. Problemem WSA jest niekiedy wyraźne zaangażowanie polityczne jej pionierów, którzy uważają, że wiązanie kwestii nauki i praktyki winno być oczywiste. Większość wspomnianych na polskim rynku prac poświęconych WSA dotyczy historii idei kapitalizmu, a także stosunku głównych przedstawicieli tego nurtu do długookresowych trendów historii. Dużo mniejszy nacisk w porównaniu do historii jest położony na nauki społeczne, choć i tu pojawiły się pewne zmiany (wspomniane prace J. Hryniewicza, T. Klementewicza i T. Zaryckiego). Takie nauki jak politologia i stosunki międzynarodowe wywodzą się w Polsce z tradycji nauk humanistycznych, tak jak historia. Wielu politologów odebrało wykształcenie historyczne i bazuje na metodologii badań historycznych. Politologiczna diagnoza znaczenia globalnych procesów społeczno-gospodarczych może zostać wzbogacona dzięki poszerzeniu badań o kwestie historyczne.

Dalsze prace w obrębie nurtu WSA obejmować będą rekonstrukcję jej dorobku w obrębie stosunków międzynarodowych, główne podejścia do WSA, wizje historii gospodarczej i jej znaczenie w polityce i gospodarce światowej, interpretację procesu globalizacji w ramach WSA, stosunek teoretyków WSA do trendów roz- 
woju globalnego handlu i wzrostu znaczenia Azji. Z punktu widzenia regionalnego ważna jest weryfikacja aktualności podziału na centra, półperyferie i peryferie oraz analiza sytuacji Polski w tym kontekście.

\section{Bibliografia:}

Agnew, J. (2001). The New Global Economy: Time-Space Compression, Geopolitics, and Global Uneven Development. Journal of World-Systems Research, 7/2, 133-154.

Aleksy, A. (2005). Teoria systemu światowego Immanuela Wallersteina oraz jej znaczenie dla teorii stosunków międzynarodowych. W: R. Kuźniar (red.) Porządek międzynarodowy u progu XXI wieku. Warszawa: Wydawnictwa Uniwersytetu Warszawskiego.

Amin, S. (1972). Accumulation on a World Scale. New York: Monthly Review Press.

Amin, S. (1994). Re-reading the Postwar Period: An Intellectual Itinerary. New York: Monthly Review Press.

Amin, S., Arrighi, G., Frank, A.G., Wallerstein, I. (1982). Dynamics of the World Economy. New York: Monthly Review Press.

Amin, S., Arrighi, G., Frank, A.G., Wallerstein, I. (1990). Transforming the Revolution. Social Movements and the World System. New York: Monthly Review Press.

Arrighi, G., Drangel, J. (1986). The Stratification of the World-Economy: An Exploration of the Semiperipheral Zone. Review, 10, 9-74.

Arrighi, G. (1994). The Long Twentieth Century: Money, Power, and the Origins of Our Times. London: Verso.

Babones, S.J. (2009). Modeling Error in Quantitative Macro-Comparative Research. Journal of World-Systems Research, XV(1), 86-114.

Babones, S.J., Chase-Dunn, Ch. (eds.). (2012). Routledge Handbook of World-Systems Analysis, London \& New York: Routledge. Taylor \& Francis.

Babones, S.J. (2015). What is World-Systems Analysis? Distinguishing Theory from Perspective. Thesis Eleven, 127(1), 3-20.

Babones, S.J. (2016). Pozycja i mobilność we współczesnej gospodarce-świecie: perspektywa strukturalistyczna. W: T. Zarycki (red.) Polska jako peryferie (s. 13-24). Warszawa: Scholar.

Bagchi, A.K. (2000). The Past and the Future of the Developmental State. Journal of World-Systems Research, 2, 398-442.

Bloch, M. (1960). Pochwata historii, czyli o zawodzie historyka. Warszawa: PWN.

Boatca, M. (2006). Semiperipheries in the World-System: Reflecting Eastern European and Latin American Experiences. Journal of World-Systems Research, 12(2), 321-346.

Braudel, F. (1971). Historia i trwanie. Warszawa: Czytelnik.

Braudel, F. (2013). Dynamika kapitalizmu. Warszawa: Aletheia.

Brewer, B. (2011). The Long Twentieth Century \& The Cultural Turn: World-Historical Origins Of The Cultural Economy. Journal of World-Systems Research, 17(1), 39-57.

Chase-Dunn, Ch., Grimes, P. (1995). World-Systems Analysis. Annual Review of Sociology. 21, 387-417. 
Chase-Dunn, Ch., Hall, T. (red.). (1997) Rise and Demise. Comparing World-Systems. Boulder: Westview Press.

Chase-Dunn, Ch. (1998). Global Formation. Structures of the World-Economy. Lanham: Rowman\&Littlefield.

Chase-Dunn, Ch. (1999). Globalization: A World-Systems Perspective. Journal of World-Systems Research, 2, 187-215.

Chase-Dunn, Ch., Anderson, E.N. (2005). The Historical Evolution of World-Systems. New York - Basingtoke: Palgrave Macmillan.

Chase-Dunn, Ch. (2013). Five Linked Crises in the Contemporary World-System. Journal of World-Systems Research, 19(2), 175-180

Czaputowicz, J. (2006). Teorie stosunków międzynarodowych. Krytyka i systematyzacja. Warszawa: Wydawnictwo Naukowe PWN.

Czaputowicz, J., Ławniczak, K., Wojciuk, A. (2015). Nauka o stosunkach międzynarodowych $i$ studia europejskie w Polsce. Warszawa: Scholar.

Danna, D. (2014). Population Dynamics and World-Systems Analysis. Journal of World-Systems Research, 20(2), 207-228.

Denemark, R.A., Friedman, J., Gills, B., Modelski, G. (2003). World System History. The Social Science of Long-term Change. New York: Routledge.

El-Ojeili, Ch. (2014). Reflections on Wallerstein: The Modern World-System, Four Decades on, Critical Sociology, 2014, 1-22.

Frank, A.G. (1991). A Plea for World System History. Journal of World History, II(1), 1-28.

Frank, A.G., Gills, B., (red.). (1993). The World System: Five Hundred Years or Five Thousand? London: Routledge.

Frank, A.G. (2000). Immanuel and Me With-Out Hyphen. Journal of World-Systems Research, 6(2), 216-231.

Friedman, H. (2000). What on Earth is the Modern World-System? Foodgetting and Territory in the Modern Era and Beyond. Journal of World-Systems Research, 6(2), 480-515.

Gałganek, A. (1992). Zmiana w globalnym systemie międzynarodowym. Supercykle i wojna hegemoniczna. Poznań: Wydawnictwo Uniwersytetu im. Adama Mickiewicza.

Gałganek, A. (2013). Historia stosunków międzynarodowych. Nierówny i połączony rozwój. Warszawa: Elipsa.

Gawrycki, M.F., Szeptycki A. (2011), Podporządkowanie-niedorozwój-wyobcowanie. Postkolonializm a stosunki międzynarodowe. Warszawa: Wydawnictwa Uniwersytetu Warszawskiego.

Gellert, P., Shefner J. (2009). People, Place, And Time: How Structural Fieldwork Helps World-Systems Analysis. Journal of World-Systems Research, XV(2), 193-218.

Goldfrank, W. (2000). Paradigm Regained? The Rules of Wallerstein's World-System Method. Journal of World-Systems Research, 6(2), 150-195.

Goldstein, J. (1988). Long Cycles: Prosperity and War in the Modern Age. New Haven: Yale University Press.

Haliżak, E.M. (red.). (2012). Geoekonomia. Warszawa: Scholar.

Hryniewicz, J. (2010). Teoria centrum-peryferie w epoce globalizacji. Studia Regionalne i Lokalne, 2(40), 5-27. 
Hryniewicz, J. (2013). Centrum-Peryferie. Stara teoria w nowych czasach. Studia Polityczne, 31, 291-313.

Ilkowski, F. (2015). Imperializm kapitalistyczny we wspótczesnych ujęciach teoretycznych, Toruń: Wydawnictwo Adam Marszałek.

Jasiecki, K. (2009). Globalizacja i kryzys socjologii rozwoju. Studia Społeczne, 1/2009, 33-52.

Jasiński, L.J. (2011). Blizej centrum czy na peryferiach? Polskie kontakty gospodarcze z zagranica wXX wieku. Warszawa: Centrum Europejskie Natolin i Wydawnictwo Trio.

Klementewicz, T. (2013). Geopolityka trwatego rozwoju. Warszawa: Elipsa.

Klementewicz, T. (2015). Stawka większa niż rynek. Uźródeł kapitalizmu bez granic. Warszawa: Książka i Prasa.

Kochanowicz, J. (1989). The Polish Economy and the Evolution of Dependency. W: D. Chirot (red.) The Origins of Backwardness in Eastern Europe (s. 92-130). Berkeley: University of California Press.

Kochanowicz, J. (2006). Backwardness and Modernization. Poland and Eastern Europe in the $16^{\text {th }}-20^{\text {th }}$ Centuries. Burlington: Ashgate.

Koźmiński A., Jemielniak D., (red.). (2008). Zarzadzanie wiedzą. Warszawa: Wydawnictwa Akademickie i Profesjonalne.

Kula, W. (1983a). Problemy i metody historii gospodarczej. Warszawa: PWN.

Kula, W. (1983b). Historia. Zacofanie. Rozwój. Warszawa: Czytelnik.

Landes, D.S. (2008), Bogactwo i nędza narodów. Warszawa: Wydawnictwo Literackie MUZA.

Leszczyński, A., (2013). Skok w nowoczesność. Polityka wzrostu w krajach peryferyjnych 1953-1980. Warszawa: Wydawnictwo Krytyki Politycznej.

Lloyd, P., Mahutga, M., De Leeuw J. (2009). Looking Back and Forging Ahead: Thirty Years of Social Network Research on the World-System. Journal of World-Systems Research, 15(1), 48-85.

Markoff J. (1999). Globalization and the Future of Democracy. Journal of World-Systems Research, 5(2), 277-309.

Małowist, M., (1966). The Problem of the Inequality of Economic Development in Europe in the Latter Middle Ages. Economic History Review, XIX(1), 15-28.

Małowist, M. (1973). Wschód a Zachód Europy w XIII-XVI wieku. Konfrontacja struktur społeczno-gospodarczych. Warszawa: PWN.

Modelski, G., Benedict R. (1974). Structural Trends in World Politics. Comparative Politics, 6(2), 287-298.

Modelski, G. (1978). The Long Cycle of Global Politics and the Nation State, Comparative Studies in Society and History, t. 20, 2(1978), 214-235.

Moran, P.T. (2009). Studying Long-Term Large-Scale Change: Concluding Reflections On The Relevant Unit Of Analysis. Journal of World-Systems Research, XV(1), 115-123.

Pawłuszko, T. (2014a). Kategoria systemu międzynarodowego w badaniach stosunków międzynarodowych. Torun: Wydawnictwo Adam Marszałek.

Pawłuszko, T. (2014b). Użyteczność analityczna kategorii systemu międzynarodowego, Stosunki Międzynarodowe - International Relations, 1(49), 9-29.

Pawłuszko, T. (2015). Droga państw nordyckich z peryferii do centrum gospodarki światowej. W: M. Tomala, M. Łuszczuk (red.). Pótnoc w przestrzeni politycznej i gospodarczej (s. 195-214). Kielce: Wydawnictwo Uniwersytetu Jana Kochanowskiego. 
Polanyi, K. (2010). Wielka transformacja. Polityczne i ekonomiczne źródta naszych czasów. Warszawa: PWN.

Polus, A. (2014). Postkolonialna teoria stosunków międzynarodowych. W: K. Kącka (red.). Stosunki międzynarodowe. Wokót zagadnień teoretycznych (s. 113-128). Toruń: Wydawnictwo Uniwersytetu Mikołaja Kopernika.

Prebisch, R. (1959). Commercial Policy in the Underdeveloped Countries. American Sociological Review, 49(2), 251-273.

Ravenhill, J. (red.). (2012) Globalna ekonomia polityczna. Kraków: Wydawnictwo Uniwersytetu Jagiellońskiego.

Rewizorski, M. (2009). Koncepcja systemu światowego według Immanuela Wallersteina. Przegląd Politologiczny, 1, 65-78.

Rojas, C.A. (2000). Rethinking Current Social Sciences: The Case of Historical Discourses in the History of Modernity. Journal of World-Systems Research, 6(3), 750-766.

Sanderson, S. (2005). World-Systems Analysis after Thirty Years. Should it Rest in Peace? International Journal of Comparative Sociology, 46(3), 179-213.

Schumpeter, J. (1960). Teoria rozwoju gospodarczego. Warszawa: PWN.

Schwartzman, K. (2006). Globalization from a World-System Perspective: A New Phase in the Core-A New Destiny for Brazil and the Semiperiphery? Journal of World-Systems Research, 12(2), 265-307.

Sklair, L. (1999). Competing Conceptions of Globalization. Journal of World-Systems Research, 5(2), 143-163.

Skocpol, T. (1977). Wallerstein's World-System: A Theoretical and Historical Critique. American Journal of Sociology, 82(5), 1075-1090.

Sosnowska A. (2004). Zrozumieć zacofanie. Spory historyków o Europę Wschodnia 1947-1994. Warszawa: Trio.

Swianiewicz, J. (2014). Możliwość makrohistorii. Braudel. Wallerstein. Deleuze. Toruń: Wydawnictwo Uniwersytetu Mikołaja Kopernika.

Terlouw, K. (2011). Five Centuries of Regional Development in Northwest Germany And The Netherlands. Journal of World-Systems Research, 17(1), 199-217.

Therborn, G. (2000). Time, Space, and Their Knowledge: The Times and Place of the World and Other Systems. Journal of World-Systems Research, 6(2), 266-284.

Topolski, J. (1977). Gospodarka polska a europejska w XVI-XVIII wieku. Poznań: Wydawnictwo Poznańskie.

Turchin, P., Adams, J., Hall, T. (2006), East-West Orientation of Historical Empires and Modern States. Journal of World-Systems Research, 12(2), 219-229.

Wallerstein, I. (1974a). The Rise and Future Demise of the World Capitalist System: Concepts for Comparative Analysis. Comparative Studies in Society and History, 16, 387-415.

Wallerstein, I. (1974b). The Modern World-System: Capitalist Agriculture and the Origins of the European World-Economy in the Sixteenth Century. New York: Academic Press.

Wallerstein, I. (1991). Geopolitics and Geoculture: Essays on the Changing World System. New York: Cambridge University Press.

Wallerstein, I. (1991). Unthinking Social Science: The Limits of Nineteenth Century Paradigms. Cambridge: Polity Press. 
Wallerstein, I. (2004). Koniec świata jaki znamy. Warszawa: Scholar.

Wallerstein, I. (2007). Analiza systemów-światów. Wprowadzenie. Warszawa: Dialog.

Wallerstein, I. (2008). Utopistyka. Alternatywy dla XXI wieku. Poznań: Bractwo Trojka.

Wallerstein, I. (2012). World-systems analysis as a knowledge movement. W: Babones, S.J. and Chase-Dunn Ch. (red.). Routledge Handbook of World-Systems Analysis (s. 515-521). Oxford: Routledge.

Wallerstein, I. (2013). Europejski uniwersalizm. Retoryka władzy. Warszawa: Scholar.

Wallerstein, I. et al. (2015). Czy kapitalizm ma przyszłość? Warszawa: Dialog.

Williams, G.P. (2013). Interview with Immanuel Wallerstein. Retrospective on the Origins of World-Systems Analysis. Journal of World-Systems Research, 19(2), 202-210.

Wojciuk, A. (2016). Imperia wiedzy. Edukacja i nauka jako czynniki sity w stosunkach międzynarodowych. Warszawa: Scholar.

Worsley, P. (1980). One World or Three? A Critique of the World-System Theory of Immanuel Wallerstein. Socialist Register 1980, s. 298-338.

Zarycki, T. (2009). Peryferie. Nowe ujęcia zależności centro-peryferyjnych. Warszawa: Scholar.

Zarycki, T. (red.). (2016). Polska jako peryferie. Warszawa: Scholar.

Ziewiec, G. (2009). Wallersteina i Fukuyamy prognozy systemu kapitalistycznego. Gospodarka Narodowa, 1-2, 27-47. 